\title{
Actual Problems and Prospects of the Pharmaceutical Market
}

\author{
Galymzhan Talassov ${ }^{1} \&$ Gulnar Abdrakhmanova ${ }^{2}$ \\ ${ }^{1}$ Kazakh British Technical University, Kazakhstan \\ ${ }^{2}$ Kazakh National Technical University named after K. I. Satpayev, Almaty, Kazakhstan \\ Correspondence: Gulnar Abdrakhmanova, Kazakh National Technical University named after K. I. Satpayev, \\ Satpaev Street, 22a, Almaty, 050013, Kazakhstan. E-mail: kairat_phd@mail.ru
}

Received: February 8, 2015 Accepted: April 4, 2015 Online Published: July 30, 2015

doi:10.5539/ass.v11n19p264 URL: http://dx.doi.org/10.5539/ass.v11n19p264

\begin{abstract}
This article describes the production of basic pharmaceutical products, the share of domestic production in the domestic market, the main capital of the pharmaceutical industry of the Republic of Kazakhstan, the volume of gross value added (GVA) of the pharmaceutical industry, labor productivity in the pharmaceutical industry, pharmaceutical industry exports for the period from 2008 to 2013, as well as the existing main problems of the pharmaceutical industry.
\end{abstract}

Keywords: Republic of Kazakhstan, the pharmaceutical market, production, fixed capital, GVA, labor productivity, export

\section{Introduction}

The pharmaceutical market is one of the most profitable and fastest-growing sectors of the world economy. It serves as a criterion for economic and social development of the country, as well as the welfare of the population. Development of the pharmaceutical industry of the state is considered to be an indicator of high innovativeness of its economy.

Given the high dependence of the Kazakhstan pharmaceutical market on foreign supplies of medicines, to create its own pharmaceutical industry is one of the priorities of the formation of the economic independence of Kazakhstan (Akhmetov, 2014, p. 198; Zhakipbekov, Kaukhova, Datkhayev, Sakipova, Yeraliyeva, \& Datkhayeva, 2014, p. 261; Shertaeva, Tulemissov, Botabayeva, Blinova, Mamytbayeva, Zhanabayev, Ibragimov, Datkhayev, \& Zhakipbekov, 2014, pp. 16-23; Utegenova, Blinova, Shertaeva, Tulemissov, Sapakbay, Umurzakhova, \& Zhakipbekov, 2013, pp. 664-672).

\section{Methods}

As on the basis of the system analysis of the domestic and foreign literature reviewed production of basic pharmaceutical products, the share of domestic production in the domestic market, the main capital of the pharmaceutical industry of the Republic of Kazakhstan, the volume of gross value added (GVA) of the pharmaceutical industry, labor productivity in the pharmaceutical industry, pharmaceutical industry exports for the period from 2008 to 2013, as well as the existing main problems of the pharmaceutical industry.

According to international market research firm IMS Health Consulting, in 2012 the volume of the global pharmaceutical market reached 940 billion dollars. The growth in monetary terms amounted to about $6 \%$. Subsequently expected annual increase of not less than $4.3 \%$, and in this case, 2016 level is reached $\$ 1.2$ trillion (Borisov, 2014; Prospects of development of the pharmaceutical market in the Common Economic Space, 2013; Datkhayev, Shopabayeva, Zhakipbekov, Yermekbayeva, Orazbekov, \& Turgumbayeva, 2013, pp. 677-683).

Today the pharmaceutical market of Kazakhstan is one of the most dynamic and fastest growing in the world. According to the Kazakh Institute of the Republic of Kazakhstan's industry volume of production of basic pharmaceutical products between 2008 and 2013 increased from 11286 million tenge to 33553 million tenge (nominal growth -3 times, the real growth - 2.2 times) (Figure 1). 


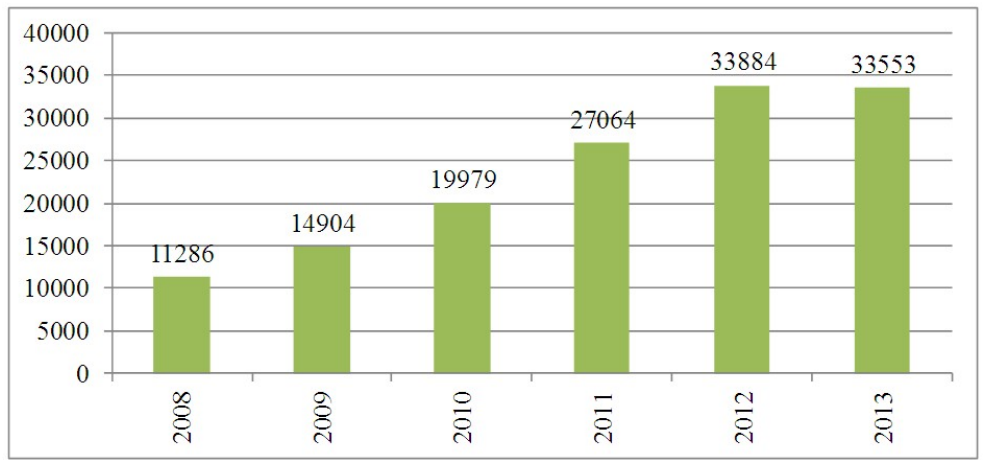

Figure 1. The volume of production of basic pharmaceutical products, mln. tenge

Source: Statistics Agency of the Republic of Kazakhstan

In January-July 2014 production wasmade by 16247 million tenge, which is in nominal terms by $21.4 \%$ below the corresponding period of the previous year.

During the period from 2008 to 2013 there was an increase in production of antibiotics 4 times (from 3,305 $\mathrm{kg}$ to $13,629 \mathrm{~kg})$.

In January-June 2014 there was a decrease by $46.3 \%$ compared with the corresponding period of the previous year $(6,525 \mathrm{~kg}$ to $3,503 \mathrm{~kg})$ (Figure 2).

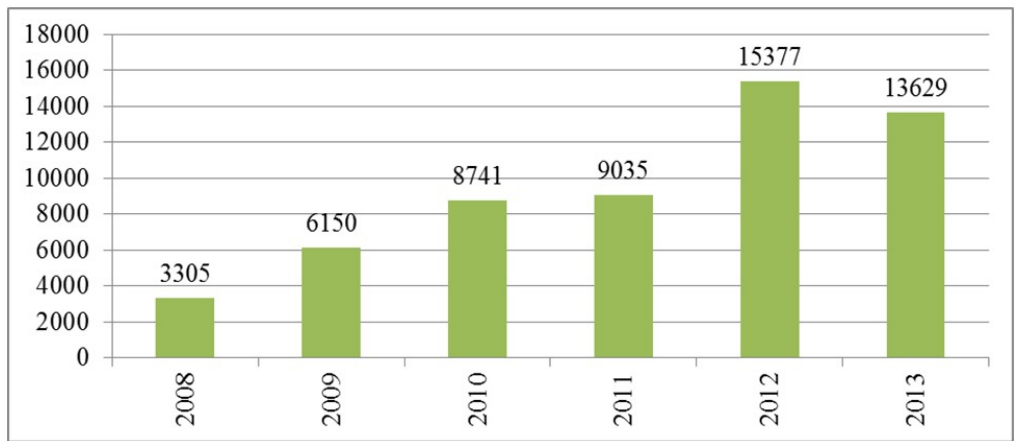

Figure 2. Production of antibiotics, $\mathrm{kg}$

Source: Statistics Agency of the Republic of Kazakhstan

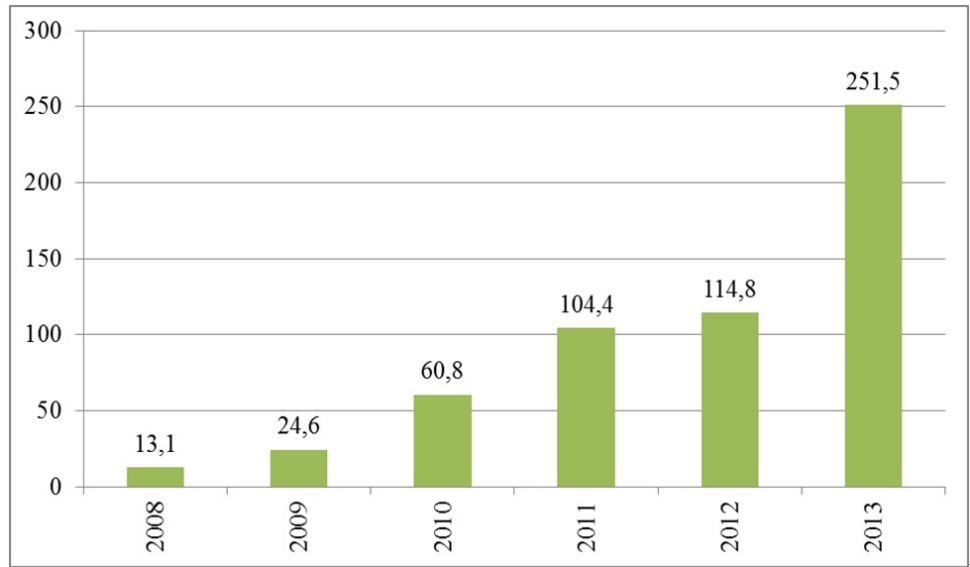

Figure 3. Production of syringes, million pieces

Source: Statistics Agency of the Republic of Kazakhstan 
In the period from 2008 to 2013, the total production of syringes increased 19 times (from 13.1 million units to 251.5 million pieces).

In January-June 2014 production volume decreased by $58.3 \%$ compared to the same period of the previous year and amounted to 59.8 million units (Figure 3).

In the period from 2008 to 2013, the share of domestic production in the domestic market increased (Figure 4 and 5):

- Pharmaceuticals - from $8.3 \%$ to $13.6 \%$;

- Antibiotics - from $7.6 \%$ to $16 \%$;

- Syringes - from $4.8 \%$ to $51.1 \%$.

In January-June 2014 the share of domestic production in the domestic market has changed compared to the same period of the previous year (Figure 6 and 7):

- Pharmaceuticals - an increase from $15.8 \%$ to $16.4 \%$;

- Antibiotics - a decrease from $14.4 \%$ to $13.1 \%$;

- Syringe - a decline from $52.8 \%$ to $44.3 \%$.

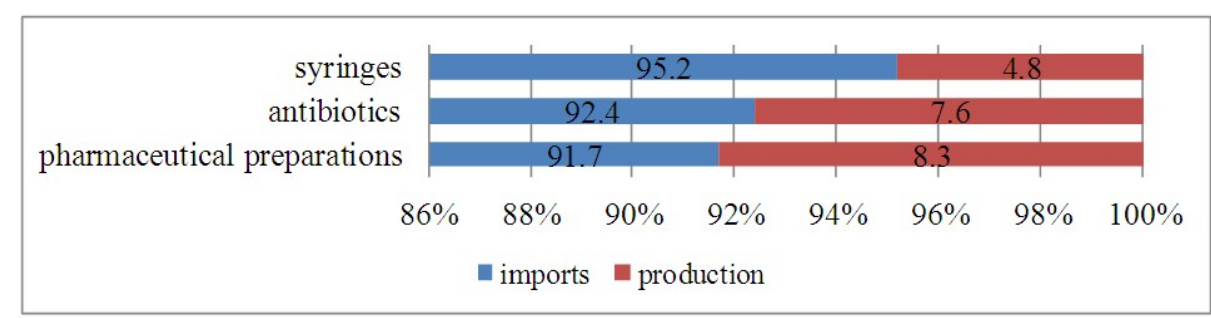

Figure 4. The share of domestic production in total resources in 2008, \%

Source: Statistics Agency of the Republic of Kazakhstan

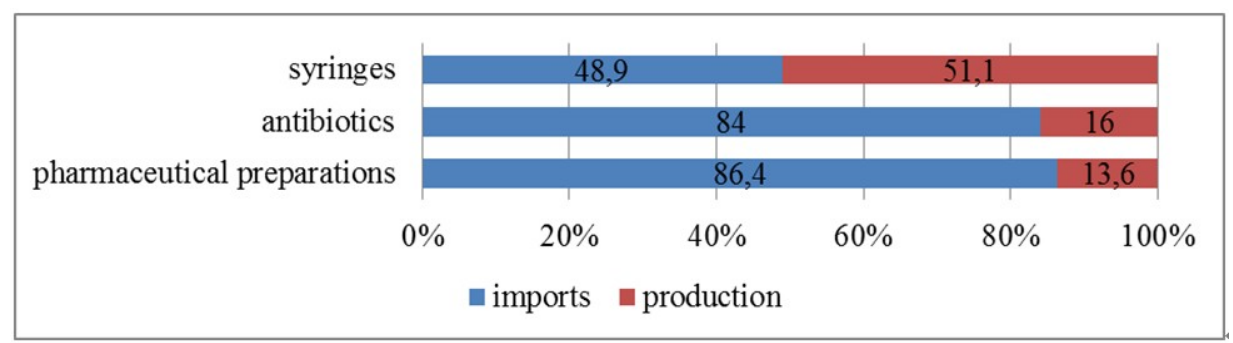

Figure 5. Share of domestic production in total resources in 2013, \%

Source: Statistics Agency of the Republic of Kazakhstan

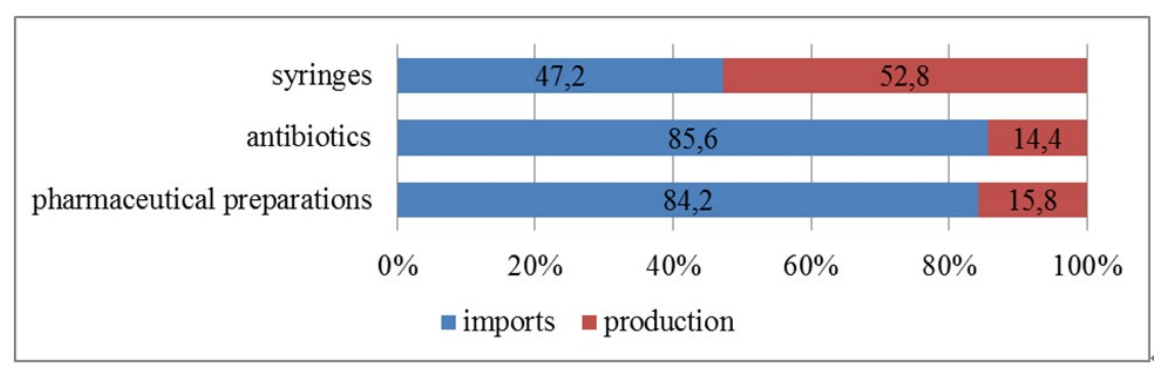

Figure 6. The share of domestic production in total resources in January-June 2013, \%

Source: Statistics Agency of the Republic of Kazakhstan 


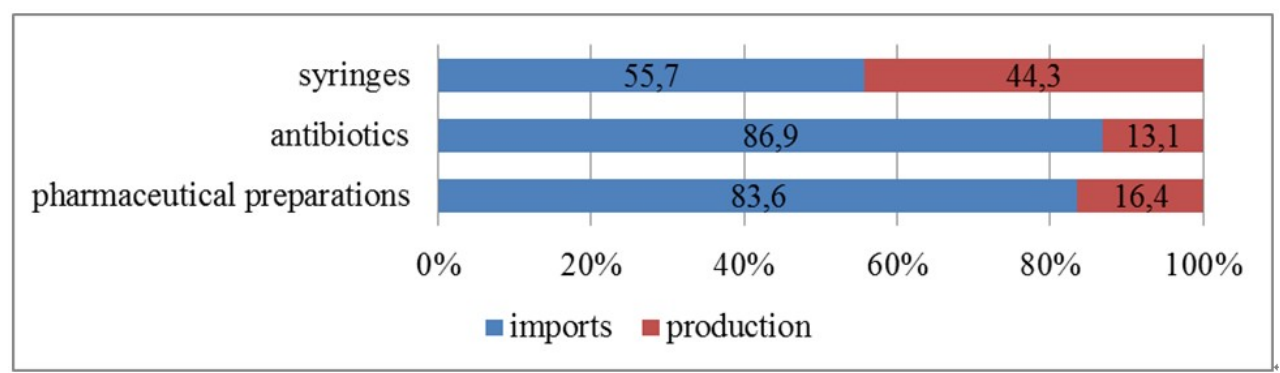

Figure 7. The share of domestic production in total resources for January-June 2014, \%

Source: Statistics Agency of the Republic of Kazakhstan

One of the objectives of the Government of the Republic of Kazakhstan is to improve conditions to attract investment and promote a positive investment image of Kazakhstan. One of the priority sectors for attracting investment in the Program is designated pharmaceutical industry (Zhakipbekov, Dathaev, Zhumabaev, \& Sakipova, 2014, pp. 108-115; Akhmetov, 2014, p. 198; Zhakipbekov, Dathaev, Zhumabaev, \& Sakipova, 2014, pp. 108-115).

In 2013, the volume of investment in fixed assets of the pharmaceutical industry of Kazakhstan amounted to 8 262.4 million tenge, the growth in nominal terms compared with 2012 (2095) - 4 times in comparison with 2009 (2239) - 36 times.

In January-July 2014 the volume of investments amounted to 6,044 mln. tenge, where only $5323 \mathrm{mln}$. tenge from own resources (Figure 8).

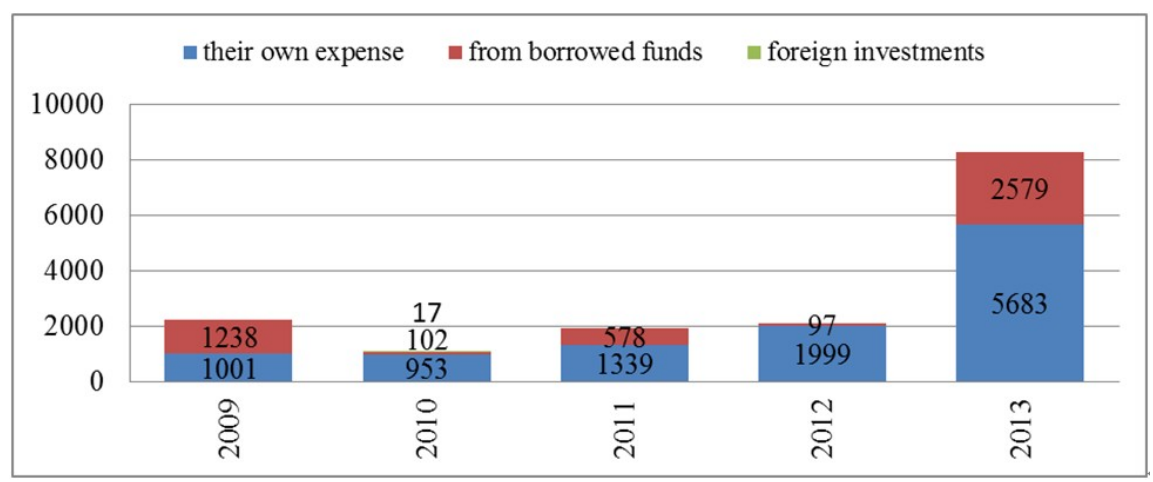

Figure 8. Investments in fixed assets of the pharmaceutical industry of the Republic of Kazakhstan, mln. tenge Source: Statistics Agency of the Republic of Kazakhstan

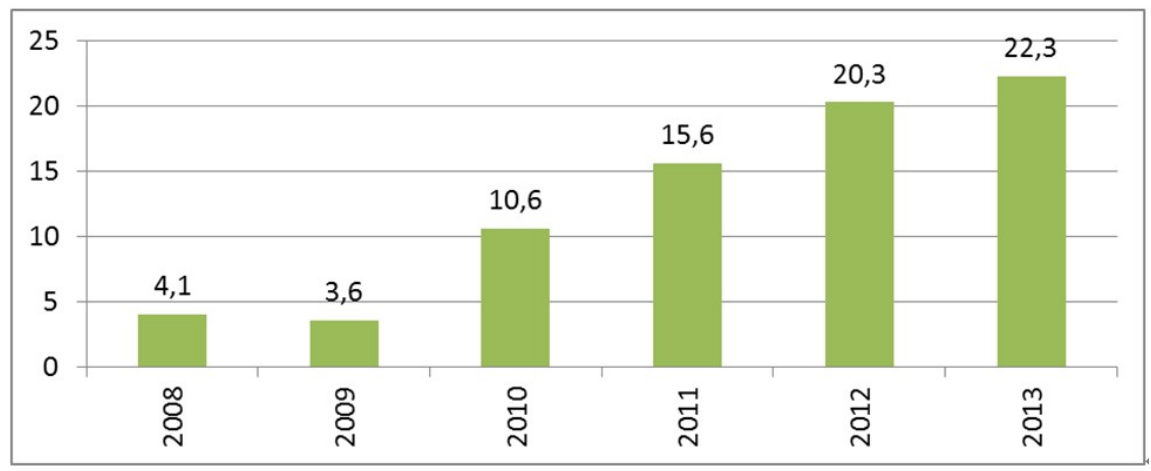

Figure 9. GVA of pharmaceutical industry, bln. tenge

Source: Statistics Agency of the Republic of Kazakhstan 
The volume of gross value added (GVA) of the pharmaceutical industry grew from 4.1 bn. tenge in 2008 to 22.3 bn. tenge in 2013 (5.4 times), in real terms in 2013 compared to 2008 - $1939 \%$.

During January-March 2014 the volume of the pharmaceutical sector GVA increased from 3.3 bn. tenge and 3.6 bn. tenge in comparison with the same period of the previous year (Figures 9 and 10).

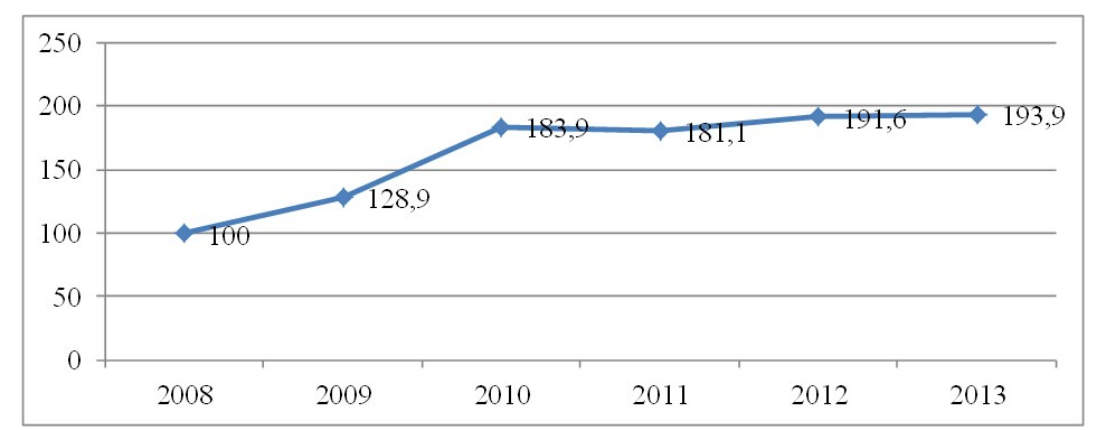

Figure 10. The real growth of GVA, \% since 2008

Source: Statistics Agency of the Republic of Kazakhstan

From 2008 to 2013, labor productivity in the pharmaceutical industry in nominal terms increased by 2.3 times (from 18.2 to 42.0 thousand US dollars), in real terms - by $212.9 \%$.

In January-June 2014, labor productivity in the pharmaceutical industry was 15.6 thousand US dollars, compared with the corresponding period of the previous year (10.5 thousand US dollars) - higher by $48.6 \%$ (volume index (IPV) - 159\%) (Figures 11 and 12).

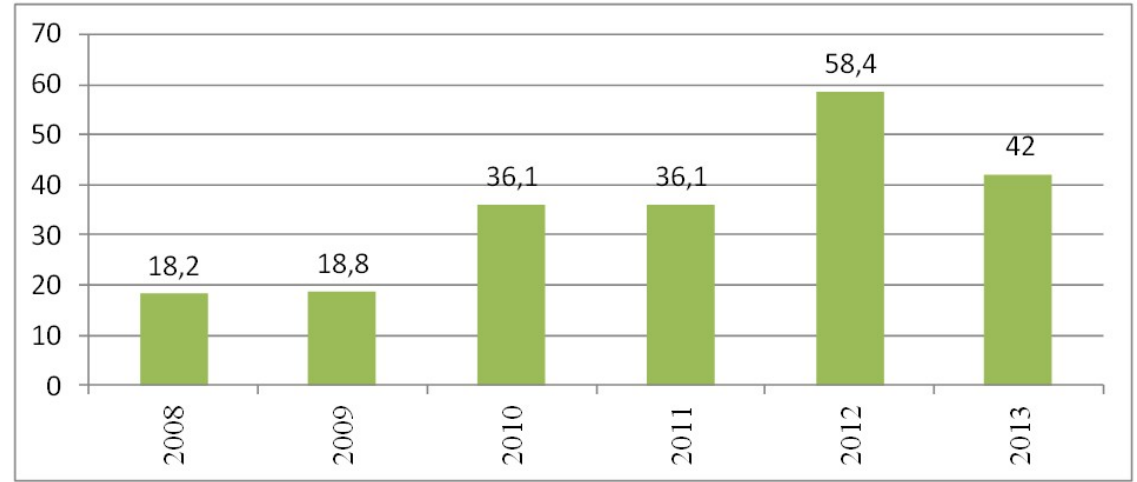

Figure 11. Labor productivity in the pharmaceutical industry, thousand US dollars/person

Source: Statistics Agency of the Republic of Kazakhstan

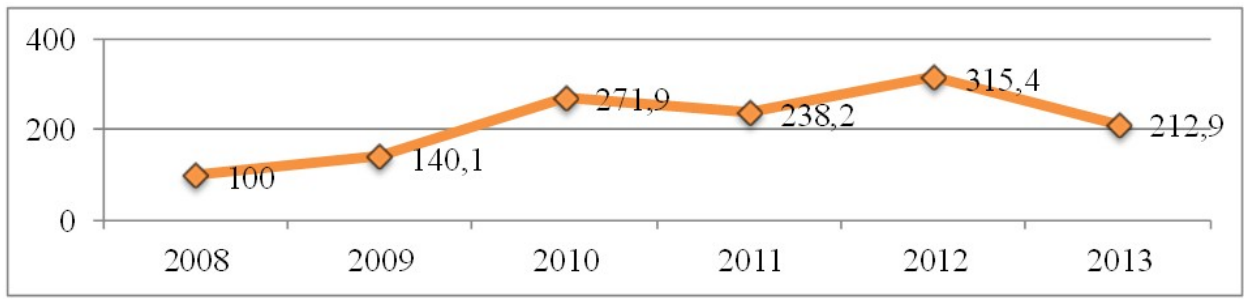

Figure 12. IPV, \% since 2008

Source: Statistics Agency of the Republic of Kazakhstan 
Exports of the pharmaceutical industry for the period from 2008 to 2013 increased by $17 \%$ (from 20.1 to 23.5 million US dollars).

In January-June 2014 exports totaled 8.9 million US dollars, which is $22 \%$ less than the same period of the previous year (Figure 13).

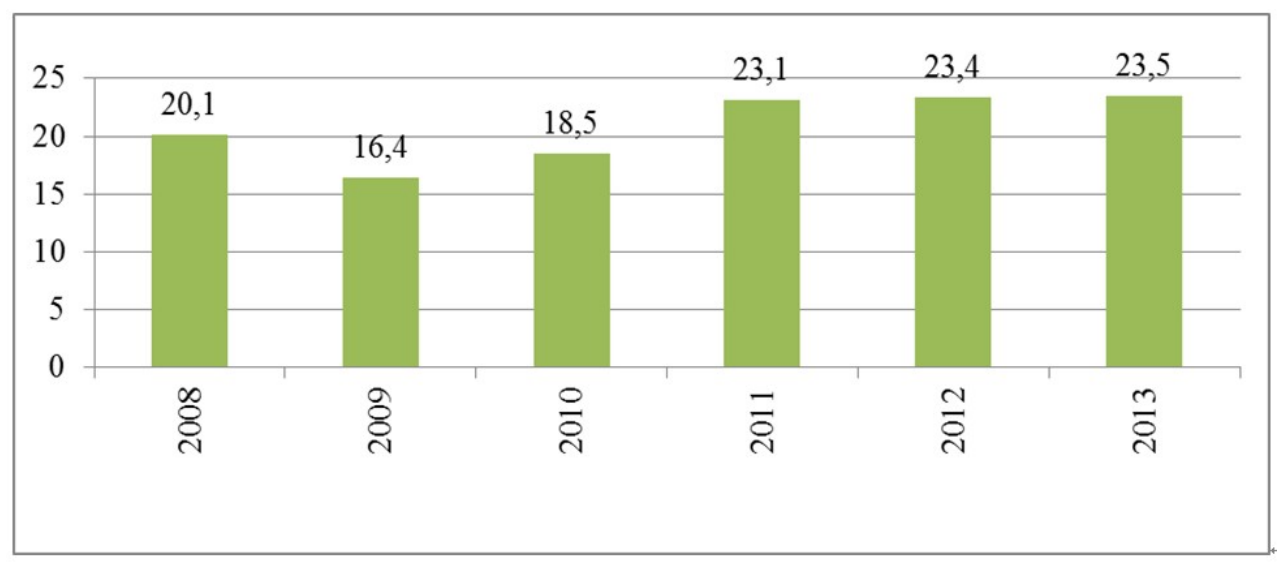

Figure 13. Export of the pharmaceutical industry, million US dollars

Source: Statistics Agency of the Republic of Kazakhstan

To date, the creation of conditions for the import of pharmaceutical and health care products based on advanced technologies in accordance with international GMP standards is one of the major challenges for the development of the pharmaceutical industry in Kazakhstan.

The state has a significant influence on the formation of the Kazakhstan pharmaceutical market - to ensure a guaranteed volume of free medical care (SBP), and domestic support in the framework of existing programs for the development of the industry.

Today in our country the activity of registration, certification, quality control of medicines, medical devices and medical equipment, as well as their advertising are regulated. A National Drug Information Center, introduced state regulation of prices for medicines purchased from the budget. Also Kazakhstan created a unified system of distribution of medicines and medical devices "SK-Pharmacy", which will ensure market transparency of public procurement of medicines, to bring it closer to existing international standards of logistics, storage and distribution.

According to the Committee of Industry, Ministry of Industry and New Technologies, a single distributor in 2010 concluded 15 long-term contracts with 14 domestic manufacturers to supply 995 kinds of medicines and medical products. Number of items on long-term contracts increased from 184 items in 2009 to over 900 in 2013. The share of domestic producers in the structure of procurement of LLP (SK-Pharmacy) was 67\% in real terms.

Today the country is actively working to attract foreign investment in the industry. In 2013 gross inflows of foreign direct investment in the pharmaceutical industry totaled $\$ 8.1$ million, which is 9 times more than in 2009.

From the presence of foreign investors in the pharmaceutical industry of Kazakhstan at large member of the Kazakhstan pharmaceutical market of "Chimfarm" 51\% of the shares acquired by well-known European company "Polpharma", resulting in the involved investment of \$100 million. In the Karaganda pharmaceutical complex came to a Russian investor - the company "Pharmstandard" with an investment of \$ 15 million. At the end of next year, the plant plans to complete the reconstruction and expansion of production under GMP standards. Another major pharmaceutical company in Turkey AbdilbrahimIlaçSan. veTic. AS acquired a 60\% stake in LLP "JV GlobalFarm". The cost of the project is \$ 60 million.

State programs for the development of the pharmaceutical industry in Kazakhstan identified a number of preferences for domestic producers. Among the key - the abolition of state registration of substances, no VAT and customs duties on equipment and supplies, designed and used in the manufacture of medicines, the priority in government procurement, long-term contracts for the guaranteed purchase of products of domestic plants that 
have implemented standards of "Good Manufacturing Practice" (GMP) and ISO 13485. Also for domestic manufacturers of pharmaceutical products compensation costs associated with the withdrawal of products to foreign markets, and cost recovery in developing a comprehensive plan for the investment project were provided.

One of the main problems identified in the sectoral program is to upgrade the existing facilities and construction of new pharmaceutical enterprises in the implementation of investment projects. The introduction of international quality standards in pharmaceutical industry "Good Manufacturing Practice" (GMP) is also important. Sectoral program aims to create the conditions for the import of pharmaceutical and health care products based on advanced technologies in accordance with international GMP standards and provide industry with qualified personnel.

Another task is to attract foreign investment in the pharmaceutical industry. The influx of foreign investment in the industry will be able to accelerate the development of pharmaceutical enterprises, improve the quality of human capital, create new jobs and attract advanced technologies, encourage their spread in the industry, and to promote the implementation of the policy on import substitution.

In Programs for the development of the pharmaceutical industry, direct sums to finance companies in the industry are not provided. However, in addition to the sectoral programs, as mentioned above, there are other programs that provide government support measures, including for the pharmaceutical industry.

Thus, in the framework of the program (Performance 2020) four domestic pharmaceutical industry reimbursed development costs/examination comprehensive plans totaling 3.2 million tenge.

Under the "Exporter 2020" for 2010-2013 seven pharmaceutical industry received a partial refund of the costs associated with the promotion of its products to foreign markets, totaling 22.8 million tenge.

Within the framework of the program "Business Road Map-2020" for the period from 2010 to July 1, 2014, 21 projects facilitated pharmaceutical sector loans totaling $\$ 5.7 \mathrm{bln}$. tenge, of which the amount of subsidies amounted to 724.8 million tenge.

As part of the program for the development of innovation and technological upgrading from 2010 to the present time, 20 projects supported the pharmaceutical industry in the amount of 224.3 million tenge.

All within the framework of the Industrialization Map put into production and 22 enterprises were modernized for the production of pharmaceuticals and medical products totaling 21.1 billion tenge.

Until the end of 2014 it is planned to introduce about 9 projects totaling 21.02 billion tenge with the creation of 691 jobs during construction and more than 1.6 thousand during operation projects.

For 2013 within the framework of the Industrialization Map the pharmaceutical industry produced goods worth 6 billion tenge, which is higher than in 2010 by 10 times. The share of products manufactured by enterprises that participated in the programs of support provided by Industrialization Map, of the total pharmaceutical production in Kazakhstan in 2013 amounted to $18 \%$, an increase over the 2010 level by $3 \%$.

Since the beginning of the adoption of sectoral programs observed increase in production of pharmaceutical products (Monthly Digest: Pharmaceutical industry, 2014).

The growth of pharmaceutical products was affected by several factors, including the measures provided for in the framework of the development of the pharmaceutical industry in 2010-2014, related to long-term contracts with domestic manufacturers for the supply of pharmaceutical products, with the launch of new production facilities and modernization of existing facilities.

The main volume of pharmaceutical production by region falls on Almaty - 49\% - and South Kazakhstan region - $37 \%$ of total production. In these regions leading manufacturers of pharmaceutical products are located: JSC (Nobel AFF) LLP (AbdiIbrahimGlobalFarm), JSC (Chimfarm), as well as the bulk of the medium-sized enterprise sector (Table 1).

Increase in the share of domestic production is associated with long-term contracts with local producers as part of the work to increase local content, as well as the launch of new production facilities and modernization of existing facilities.

The pharmaceutical industry as a developing industry is represented by a total of 79 companies - manufacturers of pharmaceutical products, including small manufacturers of medical products. The share of 6 largest plants account for more than $90 \%$ of all drugs produced in Kazakhstan in terms of money. Domestic enterprises: JSC (Chimfarm), (SP GlobalFarm), JSC (Nobel AFF), pharmaceutical companies (Romat), LLP (Nur May Farm), (Karaganda pharmaceutical complex) is a company full cycle. Now full production cycle for medical devices is 
implemented by JSC (Aktyubrentgen) (Yermagambetov, Shilmanbetov, Zhakipbekov, \& Khimenko, 2013, p. 227; Zhakipbekov, Datkhayev, Nemchenko, Shopabayeva, Zhumabayev, \& Orazbekov, 2013, pp. 278-279; Zhakipbekov, Datkhayev, Nemchenko, Shopabayeva, Zhumabayev, \& Orazbekov, 2013, pp. 323-325; Zhakipbekov, 2013, p. 261).

JSC "Himfarm" (Shymkent). Historically, the flagship of domestic pharmaceutical industry has been working more than 125 years. Major production facilities have been operated over than half a century. The first significant modernization was carried out in the mid to late 90s of the last century. In 2007, a new workshop soft dosage forms was put into operation, in compliance with good manufacturing practice. The company's management, forecasting a significant increase in the scale of production in accordance with the order of the President of the Republic of Kazakhstan Nursultan Nazarbayev to achieving a 50\% market share of domestic producers announced the construction of:

- Pharmaceutical factory for the production of solid dosage forms and powder antibiotics (Astana);

- Plant for the production of injection and infusion solutions (Shymkent), including modular technology.

To date, the product range includes solid (tablets, capsules) and sterile (injectable solutions in ampoules and antibiotics for injections in bottles) dosage forms, sterile liquid solutions, syrups, liqueurs, soft dosage forms (ointments, gels, liniments and suppositories).

JV (SP GlobalFarm) - the second company in terms of volume of production in the country. Founded in 2000 in cooperation with the South Korean party, the company produces a large scale of solid dosage forms and packages ampoule preparations, foreign-made. Despite a slight depreciation of fixed assets due to inappropriate enterprise modernization to GMP standards for existing limited areas, there were announced plans to build a factory in Almaty region (Global New Life).

LLC (Pharmaceutical company (Romat) (Pavlodar) includes plants for the production of medical devices made of polypropylene, solid dosage forms (voiced satisfaction of the department standards GMP), lower price group infusion solutions and workshop for production of biological agents. The plant works in large areas in Soviet-built buildings, modernization of which to accommodate modern plants is associated with large-scale investments. (Romat) actively announces plans to expand the range and volume of products and is in constant search for a strategic partner or investor.

JSC (Nobel AFF) - posted the first stage of production on the basis of Almaty pharmaceutical factory, a major overhaul of the building, the full cycle of production of solid and liquid dosage forms in accordance with the requirements of Good Manufacturing Practice (GMP). In 2009-2011, it made its first investment project to modernize the existing production capacity, as well as built and put into operation additional workshops for the production of medicines available in the area. During 2012-2015, the second investment project for construction in Almaty new production of sterile and non-sterile medicines is planned.

The company (Nur-May) (Almaty region) with the brand (AyatPharm) specializes in lower price range infusion solutions, packed in plastic bags today. Company's workshop was put into operation in 2005. However, the yield on the predicted power hindered because of inconsistencies between the high cost of enterprise and low prices prevailing in the market of Kazakhstan on the product under the influence of both Chinese and Russian manufacturers, and competition from in-hospital pharmacies These solutions are made (on the spot), which minimizes the transport and logistics component prices.

(International scientific-industrial holding (Phytochemistry) (Karaganda) is a major research and production complex, which includes 12 research laboratories of the chemical, pharmacological, botanical and bio-technologies, a botanical garden with an area of 42 hectares and Karaganda pharmaceutical factory $(\mathrm{KPhF})$ and LLP (Karaganda pharmaceutical complex) (KPhC). Holding has a staff of 190 employees, headed by an academician of the National Academy of Sciences of the Republic of Kazakhstan. A complete set of clinical and pharmacological studies is made in connection with 43 domestic herbal remedies, the most famous of which is the anti-cancer drug arglabin. Currently production of two drugs was launched: arglabin and salsokollin. To date, the production capacity of 850 thousand arglabin bottles and 250 thousand salsokollin tablets and capsules per year. Based on current prices, the potential revenue is estimated at 628 million tenge (4.3 million US dollars).

LLP (Karaganda pharmaceutical complex) specializes in the production of original drugs from medicinal plants and has two shops:

a) Extraction and synthesis of substances (built in 2008);

b) Sublimation and ampulation (built in 2005) - the country's only shop for the production of sterile injectable 
forms, generally in compliance with Good Manufacturing Practices (GMP).

The new management of the plant relies on a significant expansion of the range primarily due to generic drugs, including injectable included in SBP purchased Single distributor system.

LLP (SVS Pharmacy) (Aktobe) provides a full cycle of production of solid dosage forms. The building is capitally repaired, the equipment was made in 2002-2004, with minor wear. The company's plans are the construction of the second production line in accordance with the requirements of Good Manufacturing Practice (GMP).

LLP (Ekafarma) (Almaty region) - has the equipment for the production of solid dosage forms including wastage on sachets and syrups. Building was detached, modernized in 2002-2003; equipment from the European and Chinese producers, with varying degrees of wear.

JSC (Aktyubrentgen) (Aktobe) for 68 years, designs, develops and manufactures X-ray and other diagnostic equipment, including mobile and stationary X-ray machines, fluorography apparatus, X-ray systems.

In value terms, the company's productivity index is 5208 tenge (35.3 US dollars) with regard to the complexity and 5935 tenge (40.2 US dollars) in respect of capital intensity. As a result of the implementation in 2006-2008, investment project of (Aktyubrentgen) carried out a full modernization of production of X-ray equipment at the new production site, which was a determining factor in a significant improvement in the quality of its products and its consumer characteristics.

Table 1. Domestic manufacturers of biological pharmaceutical products

\begin{tabular}{|c|c|c|}
\hline $\begin{array}{l}\text { Domestic manufacturer of } \\
\text { biological pharmaceutical products }\end{array}$ & Products & Location \\
\hline LLP (Racurs and K) & $\begin{array}{l}\text { Antimicrobial drugs, antiseptics, medical, wipes cleaning, } \\
\text { soda ash, disposable wipes. }\end{array}$ & Kyzylorda \\
\hline LLP (Contact) & $\begin{array}{l}\text { Sera therapeutic and immunoglobulins, diagnostic tools, } \\
\text { Products carved from metal, chart paper, disinfectants. }\end{array}$ & Shymkent \\
\hline JSC (Interfarma-K) & $\begin{array}{l}\text { Ampicillin, pyrazinamide, sulfadimetoksin, cefuroxime, } \\
\text { doxycycline. }\end{array}$ & Astana \\
\hline LLP (Malka IL) & $\begin{array}{l}\text { Antiviral means for systemic use, antibiotics, drugs other } \\
\text { gynecological, hormone drugs for systemic use eye drops. }\end{array}$ & Karaganda \\
\hline $\begin{array}{l}\text { Almaty Pharmaceutical Factory } \\
\text { (Nobel) }\end{array}$ & $\begin{array}{l}\text { Antifungal, antiviral agents for systemic use, antibiotics of } \\
\text { the penicillin group, anti-ulcer drugs, anti-cough, colds. }\end{array}$ & Almaty \\
\hline
\end{tabular}

The development of the pharmaceutical industry in Kazakhstan provides for complex organizational, economic, technological, managerial measures aimed at the design, construction and commissioning of pharmaceutical production, the introduction of production technology, research and development work on the development and production of new competitive drugs, the creation of sources of raw materials in the regions of the domestic medicinal plant materials, training for pharmaceutical production in accordance with GMP, which ultimately should help increase domestic production (Marketing review by the pharmaceutical industry of Kazakhstan, 2013; Pharmaceutical industry of Kazakhstan, http://www.generic.kz/kazakhstan-pharmacy; Kazbekov \& Kazbekova, 2013, pp. 74-78).

\section{Discussion and Results}

The main problems of the industry are:

1. A shortage of qualified personnel. At present, the problem is the lack of qualified personnel in the pharmaceutical industry, as well as the relatively high costs for the preparation of experienced staff. Manufacturers offer better training in this field: finance training abroad and to attract foreign specialists (especially with GMP experience), making it a national priority.

2. The pharmaceutical industry is represented by a predominance of mainly generics production and products (in bulk).

3. The enterprises are in process of obtaining GMP certificates of conformity, which is the main barrier to exports.

4. The lack of guaranteed markets for products. For joint ventures and attract strategic investors for 
pharmaceutical companies and medical device manufacturers long-term guaranteed orders from the state and the guaranteed return on investment for all parties are required. As the possibility of providing guarantees for innovative projects could be signing long-term contracts (off-take) with the producers for the purchase of their drugs, medical devices produced in the framework of investment projects or joint ventures.

5. Deficiency of credit. The global financial crisis has restricted access local companies to credit markets. In a study by "Baumgartner" it was revealed that out of the planned investments in modernization enterprise plants in the amount of 35.552 billion tenge approximately 16.3 billion tenge cannot be provided by any Development Bank of Kazakhstan, nor any other public development financial institutions or local or foreign investors. Local companies have expressed interest in obtaining cheap loans for the purchase of equipment for the implementation of innovative projects, but the cost of credit resources of commercial banks during the crisis increased.

6. Scientific backwardness, underdevelopment of research, the lack of new developments and products.

7. Lack of development of production of original drugs.

8 . The constant growth of prices for drugs foreign producers, exceeding the median international prices for some products and a wide scatter (30-50\%) of prices between regions of medicines.

9. Lack of rural network objects pharmaceutical activities. In addition, the system of procurement of medicines to provide guaranteed free medical care is decentralized, and allows to quickly and smoothly to provide the population and health organizations with drugs.

10. Almost all the raw materials for the production of pharmaceuticals are imported, as well as equipment that puts more dependent domestic pharmaceutical industry.

\section{Conclusion}

Thus, the pharmaceutical market in Kazakhstan today is dependent on imported products, production of the pharmaceutical industry does not provide the necessary level of national security. Based on this analysis we can conclude that there is a huge potential for the development of the pharmaceutical industry thanks to one of the most promising domestic markets in the world, the availability of the necessary factors for the development of the sector, enhance product competitiveness and increase exports. In addition, domestic enterprises should improve industry competitiveness of products and, consequently, increasing the share of domestic production of pharmaceutical products it is necessary to expand the list of products in accordance with international GMP standards and to move the production of high-margin generic drugs to the reorientation of markets from hospitals to the retail, taking into account market of the Customs Union and the forthcoming accession to the WTO.

Given the above, we can define the following basic problems of the industry, such as: lack of qualified personnel (especially with experience GMP), the prevalence of generics and products (in bulk), the lack of conformity certificates GMP, the lack of guaranteed markets for products, lack of credit facilities, scientific backwardness, underdevelopment of research, the lack of new developments and products, the lack of development of production of original drugs, rising prices of medicines foreign manufacturers, the lack of rural network objects pharmaceutical activity, the lack of raw materials for the production of pharmaceuticals.

Thus, the pharmaceutical market in Kazakhstan today is dependent on imported products, production of the pharmaceutical industry does not provide the necessary level of national security. Based on this analysis we can conclude that there is a huge potential for the development of the pharmaceutical industry thanks to one of the most promising domestic markets in the world, the availability of the necessary factors for the development of the sector, enhance product competitiveness and increase exports.

\section{References}

Akhmetov, C. M. (n. d.). Technical and socio-economic problems: Effective ways to address them: Monograph. Novosibirsk: "Seebach", 198.

Borisov, B. (n. d.). Pharmaceutical Market SES integration needs "treatment". Business and Life, 7. Retrieved from http://www.eg-online.ru/article/238879/

Datkhayev, U., Shopabayeva, A., Zhakipbekov, K., Yermekbayeva, D., Orazbekov, E., \& Turgumbayeva, A. (2013). Basic aspects of the organization of the pharmaceutical industry. Life Sci. J., 10(7s), 677-683.

Kazbekov, B., \& Kazbekova, J. (2013). Problems and the development of the pharmaceutical industry in Kazakhstan. GISAP: Medical science, pharmacology, 74-78. Retrieved from http://www.academia.edu/ 8283459/GISAP_MEDICAL_SCIENCE_PHARMACOLOGY.PART_1 
Marketing review by the pharmaceutical industry of Kazakhstan. Retrieved December 8, 2013, from http://www.inti.kz/ekspertnye-obzory/marketingovyj-obzor-po-farmacevticheskoj-promyshlennosti-respubli ki-kazaxstan.php

Monthly Digest: Pharmaceutical industry. (2014, April). JSC (Kazakhstan Industry Development Institute). Astana. Retrieved from http://kidi.kz/uploads/posts/2014-07/6.pdf

Pharmaceutical industry of Kazakhstan. Retrieved from http://www.generic.kz/kazakhstan-pharmacy

Prospects of development of the pharmaceutical market in the Common Economic Space (p. 39). (2013). Almaty.

Shertaeva, C., Tulemissov, S., Botabayeva, R., Blinova, O., Mamytbayeva, K., Zhanabayev, N., ..., Zhakipbekov, K. (2014). Improvement of medicine provision of patients with a chronic obstructive lung illness on the basis of pharmaceutical and economical investigations. Life Sci. J., 11(9s), 16-23.

Utegenova, G., Blinova, O., Shertaeva, C., Tulemissov, S., Sapakbay, M., Umurzakhova, G., \& Zhakipbekov, K. (2013). About the standards of development and the placement of pharmacy network in the Republic of Kazakhstan. Life Sci. J., 10(12s), 664-672.

Yermagambetov, D. M., Shilmanbetov, S. A., Zhakipbekov, K. S., \& Khimenko, S. V. (2013). The role of staff in introducing GMP requirements for the pharmaceutical industry. Actual Questions of Development of New Drugs: Abstracts of XX International Scientific and Practical Conference of Young Scientist and Student $(\mathrm{p}$. 227). Kh.: Publishing Office.

Zhakipbekov, K. S. (2013). Main aspects of pharmaceutical industry designing under conditions of uncertainty I All-Russian scientific-practical conference with international participation (National Healthcare Innovations) (pp. 278-279). Sankt-Petersburg. SPb.: Publisher SPChPhA.

Zhakipbekov, K. S., Dathaev, U. M., Zhumabaev, N. J., \& Sakipova, Z. B. (2014). The current state of attracting investments in the pharmaceutical industry of the Republic of Kazakhstan. Modern medicine: aktualnyh questions/Coll. Art. Materials XXVIII Intern. scientific-practical conference. Conf, 2(28), 108-115. Novosibirsk: "Seebach".

Zhakipbekov, K. S., Datkhaev, U. M., Nemchenko, A. S., Shopabayeva, A. R., Khimenko, S. V., \& Jumabaev, N. J. (2013). The basic aspects of the National Pharmaceutical industry in the Republic of Kazakhstan. Actual Questions of Development of New Drugs: Abstracts of XX International Scientific and Practical Conference of Young Scientist and Student (p. 261). Kh.: Publishing Office.

Zhakipbekov, K. S., Datkhayev, U. M., Nemchenko, A. S., Shopabayeva, A. R., Zhumabayev, N. Zh., \& Orazbekov, E. K. (2013). Principles of designing the pharmaceutical industry in Kazakhstan. Vestnik KazNMU, 3(2), 323-325.

Zhakipbekov, K., Kaukhova, I., Datkhayev, U., Sakipova, Z., Yeraliyeva, L., \& Datkhayeva, G. (2014). Key Aspects of Pharmaceutical Engineering in Engineering Companies' Activity. Global Journal of Pharmacology, 8(2), 261-267.

\section{Copyrights}

Copyright for this article is retained by the author(s), with first publication rights granted to the journal.

This is an open-access article distributed under the terms and conditions of the Creative Commons Attribution license (http://creativecommons.org/licenses/by/3.0/). 